\title{
PENERAPAN METODE COOPERATIVE INTEGRATED READING AND COMPOSITION (CIRC) UNTUK MENINGKATKAN KEMAMPUAN SISWA DALAM BERBICARA DENGAN BAHASA INGGRIS
}

\author{
THE APPLICATION OF COOPERATIVE INTEGRATED READING AND COMPOSITION \\ (CIRC) METHOD TO IMPROVE STUDENTS' SPEAKING SKILL IN ENGLISH CLASS
}

\author{
Supriyadi \\ Sekolah Menengah Atas Negeri 3 Pati \\ Email : supriyadilanang@gmail.com
}

Naskah Masuk: 12 Pebruari 2018

Naskah Revisi: 22 Oktober 2018

Naskah Diterima: 25 Oktober 2018

\begin{abstract}
This study aims to describe the application of image media through Cooperative Integrated Reading and Composition (CIRC) method to enhance students' motivation and learning outcomes in English speaking class. In addition, the application of this method toward students which study in small groups and large groups was studied too. This study was conducted in a senior high school called SMA Negeri 3 Pati from January to June, 2017. By involving 32 students from a science class, a classroom action research was carried out in two cycles and it used qualitative and quantitative approaches. Direct observation was done to collect data and later, the data were analyzed descriptively. The results showed that the application of image media through CIRC method can improve the students' motivation as well as their learning outcomes in speaking class. In addition, the application of this method in small groups of student give better results compared to that of in large group of students.
\end{abstract}

Keywords : learning outcomes, image media, CIRC method, motivation

\begin{abstract}
ABSTRAK
Penelitian ini bertujuan untuk mendeskripsikan penggunaan media gambar melalui metode Cooperative Integrated Reading and Composition (CIRC) dalam meningkatkan motivasi dan hasil belajar berbicara (speaking) pada pelajaran Bahasa Inggris. Selain itu, studi ini bertujuan untuk mengetahui efektifitas penggunaan media gambar melalui metode CIRC yang diterapkan pada kelompok dengan jumlah anggota kelompok yang berbeda. Penelitian dilaksanakan di SMA Negeri 3 Pati mulai bulan Januari sampai bulan Juni 2017. Subyek penelitian adalah siswa kelas XI MIPA I berjumlah 32 orang. Penelitian tindakan kelas (PTK) ini dilakukan dengan dua siklus. Pendekatan penelitian yang digunakan yaitu kualitatif dan kuantitatif (mix method). Teknik pengumpulan data dengan pengamatan langsung (direct observation) selanjutnya data yang terkumpul dianalisis secara deskriptif. Hasil penelitian menunjukkan terjadi perubahan perilaku belajar dari aspek keaktifan dan motivasi belajar. Lebih lanjut, penggunaan media gambar melalui metode CIRC dapat meningkatkan motivasi dan hasil belajar berbicara (speaking) pada peserta didik. Hasil penelitian juga menunjukkan penggunaan media gambar melalui metode CIRC pada kelompok kecil (siklus II) memberikan hasil yang lebih baik dalam hal meningkatkan motivasi dan hasil belajar peserta didik dibandingkan dengan dengan apabila diterapkan dalam kelompok besar (siklus II).
\end{abstract}

Kata kunci : hasil belajar, media gambar, metode CIRC, motivasi.

\section{PENDAHULUAN}

Hasil belajar berbicara (speaking) peserta didik kelas XI MIPA 1 SMA N 3 Pati semester 2 tahun pelajaran 2016/2017 masih rendah. Hal tersebut dapat dilihat pada nilai speaking yang diperoleh para siswa masih di bawah kriteria ketuntasan minimal (KKM). KKM mata pelajaran Bahasa Inggris adalah 75. Hasil penilaian berbicara yang diadakan sebelum penelitian dilakukan menunjukkan peserta didik memperoleh nilai rata-rata 59. Hal ini 
disebabkan motivasi peserta didik dalam pembelajaran speaking rendah.

Penyebab rendahnya hasil belajar berbicara selain faktor intrinsik peserta didik adalah faktor guru. Guru bertugas merencanakan kegiatan pembelajaran di kelas. Guru seharusnya bisa menggunakan metode atau model pembelajaran yang bisa membuat peserta didik tidak cepat bosan pada pembelajaran berbicara. Terdapat 3 hal penting dalam proses pembelajaran berbicara agar hasilnya bisa meningkat, yaitu: (1) peningkatan motivasi belajar peserta didik; (2) penggunaan media pembelajaran, dan ; (3) pilihan metode yang tepat.

Cooperative Integrated Reading and Composition (CIRC) termasuk salah satu model pembelajaran kooperatif terpadu membaca dan menulis. Beberapa peneliti telah melakukan studi tentang penggunaan metode CIRC dalam pembelajaran Bahasa Inggris. Penelitian yang dilakukan oleh Puspitasari \& Hidayat (2018) berfokus pada penggunaan CIRC untuk meningkatkan keaktifan siswa dalam pelajaran bahasa Inggris. Sementara Sulistiyani (2017) serta Hadiwinarto \& Novianti (2016) melakukan studi tentang penggunaan CIRC untuk meningkatkan kemampuan membaca dan menulis pada pelajaran bahasa Inggris bagi siswa sekolah menengah pertama (SMP).

Penelitian tentang penerapan CIRC untuk meningkatkan motivasi sekaligus hasil belajar berbicara dalam pelajaran bahasa Inggris belum banyak dilakukan. Penelitian ini bertujuan untuk mengetahui efektifitas penggunaan media gambar melalui metode CIRC dalam meningkatkan motivasi dan hasil belajar berbicara (speaking). Lebih jauh, peneliti dalam studi ini ingin mengetahui efektifitas penggunaan media gambar melalui metode CIRC yang diterapkan pada kelompok dengan jumlah anggota kelompok yang berbeda.

\section{TINJAUAN PUSTAKA}

\section{Hakikat Belajar}

Belajar pada hakekatnya adalah usaha untuk melakukan perubahan, baik perubahan tingkah laku maupun pengetahuan yang dilakukan secara sadar agar hidup orang menjadi lebih baik. Menurut Brown (2008), pembelajaran adalah penguasaan atau pemerolehan pengetahuan tentang suatu subjek atau sebuah keterampilan dengan belajar, pengalaman, atau instruksi. Pembelajaran dapat dilakukan melalui usaha untuk memperoleh pengetahuan atau keterampilan melalui usahausaha belajar dan pengalaman melalui instruksi atau perintah dari guru atau pembimbing.

Perubahan dapat dilakukan melalui proses belajar. Hasil belajar merupakan kemampuan akhir yang dimiliki pembelajar setelah mengalami proses dalam kurun waktu tertentu. Hasil belajar dipengaruhi faktor instrinsik maupun ekstrinsik.

\section{Media Pembelajaran}

Menurut Haryanto (2012), gambar termasuk media pembelajaran berbasis visual. Media gambar dapat menyuguhkan elaborasi yang menarik tentang struktur atau organisasi suatu hal sehingga memperkuat ingatan. Media gambar dapat menumbuhkan minat peserta didik dan memperjelas hubungan antara isi materi pembelajaran dengan dunia nyata.

Hasil belajar juga dipengaruhi oleh motivasi peserta didik, oleh karena itu perlu upaya untuk meningkatkan motivasi belajar peserta didik dalam proses pembelajaran. Salah satu caranya melalui penggunaan media pembelajaran. Media pembelajaran diyakini dapat menyalurkan pesan, merangsang pikiran, perasaan, dan kemauan peserta didik sehingga dapat mendorong terciptanya proses belajar pada diri peserta didik dengan baik. Menurut 
Haryanto (2010), media pembelajaran secara umum adalah alat bantu proses belajar mengajar. Jenis media pembelajaran antara lain media visual, media audial, projected still media, projected motion.

Penggunaan media gambar dalam pembelajaran merupakan salah satu model pembelajaran kooperatif yang memungkinkan peserta didik menjadi lebih tertarik belajar atau termotivasi dalam proses pembelajaran. Pembelajaran kooperatif merupakan salah satu model pembelajaran yang memungkinkan peserta didik berinteraksi aktif dengan lingkungan atau peserta didik lainnya, sehingga tercipta suasana pembelajaran yang hidup.

\section{Metode CIRC}

Metode CIRC termasuk dalam pembelajaraan kooperatif. Menurut Suyatno (2009), model pembelajaran kooperatif adalah kegiatan pembelajaran yang dilakukan dengan berkelompok atau bekerja sama, saling membantu dan menemukan dan membangun pengetahuan yang baru. Belajar kelompok merupakan model pembelajaran yang kooperatif. Hal ini disebabkan saat belajar dalam kelompok, peserta didik bisa mengembangkan diri sebagai makhluk individu sekaligus sebagai mahkluk sosial untuk berinteraksi dan kerjasama dengan anggota lainnya.

Pola belajar kelompok dengan cara kerjasama antar peserta didik secara alamiah dapat mendorong timbulnya gagasan yang lebih bermutu, meningkatkan kreativitas serta motivasi peserta didik. Selain itu, pembelajaran kelompok juga dapat mengembangkan karakter dan kepribadian peserta didik serta nilai sosial bangsa Indonesia yang perlu dipertahankan. Ketergantungan timbal balik antar peserta didik memotivasi mereka untuk dapat bekerja lebih keras untuk keberhasilan mereka. Hubungan kooperatif juga mendorong peserta didik untuk menghargai gagasan temannya bukan sebaliknya. Oleh karena itu pembelajaran 1 dan dapat diterima dalam teks naratif.

\section{Motivasi dan Hasil Belajar}

Mc. Donald dalam Hamalik (2001) mendefinisikan motivasi adalah perubahan energi dalam diri (pribadi) seseorang yang ditandai dengan timbulnya perasaan dan reaksi untuk mencapai tujuan. Definisi ini menunjukkan ada tiga unsur yang saling terkait yaitu: (1) Motivasi dimulai dari adanya perubahan energi dalam pribadi; (2) Motivasi ditandai dengan timbulnya perasaan; dan (3) Motivasi ditandai dengan reaksi-reaksi untuk mencapai tujuan.

Hasil belajar adalah kemampuankemampuan yang dimiliki siswa setelah menerima pengalaman belajarnya. Horwart Kingsley dalam Sudjana (2005) membagi tiga macam hasil belajar mengajar: 1) Keterampilan dan kebiasaan; 2) Pengetahuan dan pengarahan; 3) Sikap dan cita-cita. Pembelajaran bahasa Inggris merupakan pembelajaran yang mengintegrasikan empat keterampilan berbahasa, yaitu listening, speaking, reading, dan writing. Empat hal tersebut merupakan dasar dari tujuan penggunaan bahasa sebagai alat komunikasi, baik secara lisan maupun tertulis.

\section{METODE PENELITIAN}

Penelitian ini dilaksanakan dengan metode penelitian tindakan kelas (PTK). Penelitian berlangsung selama 6 (enam) bulan, dimulai pada bulan Januari sampai dengan bulan Juni 2017. Pelajaran Bahasa Inggris dilakukan 4 jam per minggu. Lokasi penelitian di SMA 3 Pati dengan subyek penelitian adalah peserta didik kelas XI MIPA 1 semester 2 tahun 2016/2017 yang berjumlah 32 orang 
terdiri dari 8 (delapan) orang peserta didik putra dan 24 (dua puluh empat) orang peserta didik putri.

Peneliti mengembangkan model pembelajaran kelompok dengan metode CIRC. Prinsip yang peneliti ambil dalam metode pembelajaran CIRC ini adalah adanya kerja kelompok (cooperative), membaca gambar secara seksama bersama kelompok (integrated reading), dan menyusun teks lisan (integrated composition). Kegiatan pembelajaran dilakukan melalui pengamatan gambar secara berkelompok, kemudian menyusun kosa kata atau vocabs yang diperoleh dari gambar tersebut, dan akhirnya menyusunnya dalam bentuk komposisi karangan. Pada akhirnya peserta didik memperoleh bekal untuk mengikuti tes speaking di kelasnya dengan penuh percaya diri.

Peneliti menggunakan media gambar dalam kelompok pembelajaran untuk memacu motivasi peserta didik dalam mengikuti proses pembelajaran berbicara Peserta didik diharapkan dapat mengembangkan potensi yang ada pada masing-masing individu dalam kelompok agar tercapai tujuan pembelajaran.

Penelitian ini menggunakan pendekatan kualitatif dan kuantitatif secara bersama-sama (mix method). Teknik pengumpulan data dengan pengamatan langsung (direct observation). Data yang terkumpul selanjutnya dianalisis secara deskriptif. Analisis dilakukan dengan membandingkan hasil pengamatan pada tiga kondisi yaitu kondisi awal, kondisi pasca siklus I dan kondisi pasca siklus II.

Penelitian ini dilakukan dengan 2 siklus tindakan yakni siklus I dan siklus II. Setiap siklus terdiri dari 4 tahapan yaitu; 1) Perencanaan (Planning); 2) Pelaksanaan (Acting); 3) Pengamatan (Observing), dan; 4) Refleksi (Reflecting). Peneliti melakukan pembelajaran pada hari dan jam yang telah direncanakan dan sesuai dengan Rencana Pelaksanaan Pembelajaran (RPP) yang telah disusun.

Kegiatan pada siklus I yaitu guru membentuk 5 kelompok peserta didik dari jumlah 32 peserta didik. Setiap kelompok peserta didik diberikan satu set gambar sesuai dengan genre yang telah disediakan narrative, dengan ketentuan setiap kelompok memperoleh gambar yang berbeda. Secara berkelompok, peserta didik memperbanyak vocabulary yang sesuai dengan genre narrative berdasar gambar yang diterima. Guru memberikan bimbingan kelompok dan menilai ke setiap kelompok seberapa jauh aktifitas peserta didik (penilaian proses), dan dilanjutkan pemberian tes performance lisan.

Prosedur penelitian pada siklus II dimulai dengan menyiapkan media dan rubrik penilaian siklus II. Peneliti mempersiapkan dua rubrik penilaian hasil untuk penilaian pada siklus II. Kegiatan pembelajaran seperti pada siklus I hanya berbeda pada pembagian kelompok peserta didik. Peserta didik dibagi menjadi 5 (lima) kelompok pada siklus I sedangkan pada siklus II, peserta didik dibagi menjadi 10 kelompok sehingga anggota kelompok menjadi lebih kecil, yaitu rata-rata 3 orang.

\section{HASIL DAN PEMBAHASAN}

\section{Kondisi Awal}

Kondisi awal sebelum dilakukan tindakan menunjukkan hasil belajar speaking rendah dengan nilai rata-rata 59. Demikian juga, pada saat proses pembelajaran, banyak peserta didik yang mengalami kesulitan untuk berkonsentrasi sehingga tidak fokus dalam mengikuti proses pembelajaran.

Berdasarkan pengamatan awal yang diadakan sebelum penelitian diperoleh hasil bahwa sebagian besar peserta didik tidak 
bersemangat dalam mengikuti pelajaran speaking. Hanya 1 dari 7 peserta didik putra $14 \%$, yang berani mengungkapkan makna lisan dalam konteks atau pokok bahasan dalam proses pembelajaran di kelas. Adapun peserta didik putri yang berjumlah 24 orang, hanya 2 orang $(8 \%)$ yang berani mengungkapkan makna lisan dalam pokok bahasan yang menjadi topik dalam proses pembelajaran speaking.

\section{Siklus I}

Berdasarkan penilaian pasca siklus I, sebanyak 20 peserta didik (64\%) berhasil mencapai KKM sekolah 75 atau lebih, sedangkan yang belum mencapai batas ketuntasan sebanyak 12 peserta didik (35\%). Nilai ratarata kelas adalah 72 (tujuh puluh dua).

Saat proses pembelajaran berlangsung, kolaborator atau observer melakukan pengamatan tentang motivasi atau antusias peserta didik pada kelompok masing-masing. Hasil pengamatan menunjukkan bahwa suasana pembelajaran yang cooperative. Peserta didik yang kurang aktif atau motivasinya kurang sebanyak 12 peserta didik dan yang mengikuti proses pembelajaran dengan motivasi cukup, sebanyak 10 orang, motivasi baik sebanyak 9 orang, dan motivasi amat baik sebanyak 1 orang peserta didik. Jadi jumlah peserta didik yang mempunyai motivasi dalam pembelajaran speaking pada siklus I sebanyak 20 orang.

\section{Siklus II}

Hasil tes speaking yang diadakan sesudah pelaksanaan tindakan siklus II menunjukkan bahwa terdapat 26 dari 32 peserta didik kelas tersebut $(81 \%)$ yang mencapai nilai di atas KKM. Sebanyak 6 peserta didik lainnya (19\%) memperoleh nilai di bawah KKM. Jumlah 32 peserta didik yang mencapai nilai di atas $\mathrm{KKM}$ itu terdiri dari peserta didik yang mencapai rentang nilai 7580 sebanyak 8 orang, rentang nilai $81-90$ sebanyak 12 orang, dan rentang nilai 91-100 sebanyak 6 orang.

Catatan pengamatan terhadap jalannya proses pembelajaran pada pelaksanaan siklus II memperlihatkan bahwa jumlah peserta didik yang mengalami kesulitan berkonsentrasi saat pelajaran speaking berkurang. Jumlah peserta didik yang cenderung panik ketika memperoleh kesempatan untuk maju di depan kelas menyampaikan teks lisan atau berbicara berkurang drastis dibandingkan dengan kondisi awal.

\section{Antar Siklus}

Hasil belajar pada siklus I diperoleh nilai rata-rata 72. Hal ini berarti dibandingkan dengan hasil belajar pada kondisi awal, terjadi peningkatan 13 point. Peneliti sudah menggunakan media gambar dalam pembelajaran speaking dengan metode CIRC pada siklus I. Saat proses pembelajaran, sebagian peserta didik dapat berkonsentrasi dalam mengikuti pembelajaran meskipun kemampuan tersebut tidak dapat merata pada semua anggota kelompok. Hal ini diduga disebabkan mereka mengikuti pembelajaran pada kelompok besar yang terdiri dari 6-7 orang. Jumlah anggota kelompok yang banyak menyebabkan kesempatan untuk mengungkapkan pendapat atau gagasan masih sedikit dan peserta didik masih malu-malu dalam menyampaikan gagasannya.

Hasil belajar pada siklus II diperoleh nilai rata-rata 81 . Hal ini menunjukkan nilai hasil belajar meningkat 22 poin $(37 \%)$ dibandingkan dengan kondisi awal dan meningkat 9 point (12\%) dibandingkan dengan hasil belajar rata-rata pada siklus I. Kegiatan pada siklus II memungkinkan peserta didik bisa mempertahankan konsentrasi belajarnya hingga akhir pelajaran selesai. Rerata hasil belajar dan jumlah peserta didik yang aktif dari kondisi awal hingga kondisi akhir pasca tindakan siklus II disajikan pada Tabel 1. 
Tabel 1.

Rekapitulasi Hasil Belajar pada Setiap Siklus

\begin{tabular}{llcc}
\hline \multirow{2}{*}{ No } & \multirow{2}{*}{ Tahapan } & Rerata & Rerata \\
\cline { 3 - 4 } & & Hasil Belajar & Jumlah Anak aktif \\
\hline 1 & Awal & 59 & 8 \\
2 & Siklus I & 72 & 20 \\
3 & Siklus II & 81 & 25 \\
\hline
\end{tabular}

Sumber : Data primer

Peneliti belum menggunakan media gambar dengan metode CIRC pada kondisi awal dalam proses pembelajaran berbicara. Hasilnya nilai hasil belajar speaking masih rendah, yaitu rata-rata 59. Demikian juga, pada saat proses pembelajaran, banyak peserta didik yang mengalami kesulitan untuk berkonsentrasi, sehingga tidak fokus dalam mengikuti proses pembelajaran karena motivasi belajar mereka juga rendah.

Peneliti sudah menggunakan media gambar dalam pembelajaran berbicara dengan metode CIRC pada siklus I (kelompok besar). Penggunaan media gambar melalui metode CIRC dapat membantu siswa untuk lebih berkonsentrasi dalam mengikuti pembelajaran yang pada akhirnya berdampak pada terjadinya peningkatan motivasi dan hasil belajar speaking.

Pembelajaran melalui metode CIRC pada kelompok kecil (siklus II), ternyata mampu meningkatkan motivasi dan hasil belajar berbicara peserta didik dibandingkan dengan apabila diterapkan pada kelompok besar (siklus I). Hal ini diduga disebabkan karena para peserta didik bisa mempertahankan konsentrasi belajarnya hingga akhir pelajaran selesai. Jumlah peserta didik yang mencapai nilai di atas KKM pada siklus II sebanyak 25 peserta didik dari 32 peserta didik kelas tersebut $81 \%$. Sedangkan 6 peserta didik lainnya $19 \%$ memperoleh nilai dibawah KKM yang ditetapkan sekolah. Jumlah 25 peserta didik yang mencapai nilai di atas KKM itu terdiri dari peserta didik yang mencapai rentang nilai 75-80 sebanyak 8 orang, rentang nilai 81-90 sebanyak 11 orang, dan rentang nilai 91-100 sebanyak 6 orang peserta didik.

Berdasarkan hasil penelitian pada siklus I dan II, dapat diketahui bahwa penggunaan media gambar dalam proses pembelajaran berbicara dapat meningkatkan hasil belajar peserta didik. Penggunaan media gambar melalui metode CIRC juga mampu meningkatkan hasil belajar speaking yang semula rata-rata hanya 59 kemudian meningkat pada siklus I menjadi 72 dan siklus II menjadi 81.

Jumlah siswa yang memiliki motivasi untuk aktif dan nilai hasil belajar peserta didik pada siklus I dan II juga meningkat dibandingkan dengan motivasi dan nilai hasil belajar pada kondisi awal. Peserta didik yang memiliki motivasi untuk aktif pada kondisi awal hanya 8 orang atau $26 \%$ dari total siswa. Siswa yang memiliki motivasi baik meningkat pada siklus I menjadi 20 peserta didik atau $62 \%$ dari total siswa dan pada siklus II menjadi 25 orang atau $81 \%$ dari total siswa.

Hasil pengamatan juga menunjukkan bahwa penggunaan media gambar melalui metode CIRC dapat membantu peserta didik untuk berkonsentrasi dalam mengikuti pembelajaran berbicara. Penggunaan media gambar juga membantu peserta didik bersikap antusias dalam merangkai dan menyusun kalimat untuk persiapan speaking dan tidak panik. Kondisi atau sikap tersebut dibutuhkan dalam pembe- 
lajaran bahasa Inggris, khususnya speaking. Penggunaan media gambar yang dikombinasikan dengan metode CIRC, dapat meningkatkan motivasi gairah belajar peserta didik.

Berdasarkan hasil penelitian, penerapan metode CIRC pada kelompok kecil (siklus II) memberikan hasil yang lebih baik dibandingkan dengan penerapan pada kelompok besar (siklus I). Jumlah peserta didik pada siklus II yang memiliki motivasi untuk aktif sebanyak 25 siswa. Hal ini berarti meningkat 25\% dibandingkan dengan jumlah peserta didik yang memiliki motivasi untuk aktif pada siklus I yang berjumlah 20 siswa. Rerata nilai hasil belajar pasca siklus II juga mengalami peningkatan $12 \%$ dibandingkan dengan rerata nilai hasil belajar pasca siklus I.

\section{KESIMPULAN DAN SARAN}

\section{Kesimpulan}

Penggunaan media gambar dengan metode CIRC dapat meningkatkan motivasi peserta didik untuk aktif belajar speaking pada pelajaran Bahasa Inggris sekaligus meningkatkan hasil belajar speaking. Penerapan media gambar dengan metode CIRC untuk pembelajaran speaking pada kelompok kecil memberikan hasil yang lebih baik dalam hal meningkatkan motivasi siswa dan hasil belajar dibandingkan dengan apabila diterapkan pada kelompok besar.

\section{Saran}

Peserta didik diharapkan dapat memanfaatkan waktu dengan efektif dan efisien dalam belajar bahasa Inggris, khususnya berbicara. Guru dapat menggunakan media gambar dengan metode CIRC dalam mengajarkan bahasa Inggris, khususnya berbicara. Sekolah diharapkan dapat memberi fasilitas yang mendukung penggunaan media pembelajaran dan metode yang sesuai dalam pembelajaran di kelas khususnya dalam pembelajaran berbicara.

\section{DAFTAR PUSTAKA}

Brown, D. H. (2008). Prinsip Pembelajaran dan Pengajaran Bahasa; edisi kelima. Jakarta: Pearson Eduction, Inc.

Puspitasari, C. A., Hidayat, D. (2018). The Implementation of the Cooperative Integrated Reading and Composition Technique to Increase Grade 8 Students' Active Learning in an English Class. Polyglot, 14(2), 223-238

Hadiwinarto., Novianti. (2015). The Effects of Using CIRC Model on the English Learning Skills among Junior High School Students. Journal of Education and Learning, 9(2), 117-124.

Hamalik, O. (2001). Kurikulum dan Pembelajaran. Jakarta: PT. Bumi Aksara.

Haryanto. (2012). Pengertian Media Pembelajaran. http://belajarpsikologi. com/ pengertian-media-pembelajaran/ Diakses 25 Maret 2013.

Haryanto. (2010). Belajar Psikologi. http:// belajarpsikologi.com/ macam-macamteori-belajar/Diakses 08 Februari 2013

Muryati, S. (2006). English Communication Competency Improvement on Spoken and Written Narrative Text Through "VCD Cutting" Media in Semarang 7 Senior High School. Laporan Penelitian. Semarang : SMA Negeri 7

Nurlina. (2011). Peningkatan Penguasaan Vocabulary dalam Konsep Reading Melalui Penerapan Metode Guess Word pada Peserta didik Kelas XII IPA SMA Negeri 3 Bireuen. Skripsi. Universitas Bireuen. 
Nur, M. (2005). Pembelajaran Kooperatif. Surabaya: Pusat Saint dan Matematika Sekolah UNESA.

Sudjana. (2005). Penilaian Hasil Proses Belajar Mengajar. Jakarta: Ganeca Exact.

Sulistiyani, W. (2017). Penerapan Metode CIRC Untuk Meningkatkan Kemampuan Menulis Descriptive Melalui Media Permainan Kartu Jack \& Jacky. Langsat Jurnal Ilmiah Pendidikan dan Sosial, $4(2), 17-22$
Suyatno. (2009). Menjelajah Pembelajaran Inovatif. Sidoarjo: Masmedia Buana Pustaka.

\section{BIODATA PENULIS}

Supriyadi, lahir di Pati pada tanggal 16 November 1966. Menyelesaikan studi S1 pada jurusan Pendidikan Bahasa Inggris di Universitas Muria Kudus tahun 1992. Gelar Magister Sains (M.Si) diperoleh dari UNISBANK Semarang pada tahun 2015. Saat ini bekerja sebagai guru mata pelajaran Bahasa Inggris di SMA Negeri 3 Pati. 